\title{
Association between $M D R 1$ gene of gastrointestinal tumors, the expression of P-glycoprotein and resistance to chemotherapeutic drugs
}

\author{
JIAN-LI SU ${ }^{1 *}$, CHENG-HONG WANG ${ }^{2 *}$, HONG-GANG KANG ${ }^{3}$, JING ZHANG $^{3}$, \\ BAO-ZHONG WANG ${ }^{3}$, MEI-RONG LIU ${ }^{3}$, JUN ZHAO ${ }^{3}$ and LIN LIU $^{4}$
}

\author{
${ }^{1}$ Department of Laboratory Medicine, Qilu Hospital of Shandong University, Qingdao, Shandong 266000; \\ ${ }^{2}$ Department of Laboratory Medicine, Yantaishan Hospital, Yantai, Shandong 264000; ${ }^{3}$ Department of Oncology, \\ Liaocheng People's Hospital, Liaocheng, Shandong 252000; ${ }^{4}$ Department of Pharmacy, Qingdao Women \\ and Children's Hospital, Qingdao, Shandong 266000, P.R. China
}

Received March 8, 2016; Accepted February 22, 2017

DOI: $10.3892 / 01.2017 .6642$

\begin{abstract}
The aim of the present study was to examine and discuss the association between multidrug resistance 1 gene $(M D R l)$ of gastrointestinal tumors, the expression of P-glycoprotein and resistance to chemotherapeutic drugs. In this study, 126 cases of patients with gastrointestinal tumors admitted to hospital from February 2013 to February 2015 were selected. The expression levels of MDRl gene were obsreved in the control population and patients before and after treatment by fluoresecent quantitative PCR. The protein expression level of P-glycoprotein was determined using western blotting and enzyme-linked immunosorbent assay. In addition, drug resistance was assessed by ATP-TCA chemosensitivity experiments. The results showed that before treatment, the expression of mRNA in MDR1 of tissues of gastrointestinal tract of the 126 cases was 108-fold larger than that of the gastrointestinal tract of the controls $(\mathrm{p}<0.05), \mathrm{P}$-glycoprotein was 87 -fold larger than the expression level of the controls $(p<0.05)$. The sensitivity of 126 tumor tissues to different chemotherapeutic drugs was determined, and the results showed that most of the tumor tissues were sensitive to chemotherapeutic drugs, and the sensitivity rate reached $96.4 \%$. Following chemotherapy, the expression of mRNA in MDR1 of tumor tissues and the expression of P-glycoprotein decreased $(\mathrm{p}<0.05)$. In conclusion, the $M D R 1$ gene and P-glycoprotein have a positive correlation
\end{abstract}

Correspondence to: Dr Lin Liu, Department of Pharmacy, Qingdao Women and Children's Hospital, 6 Tongfu Road, Qingdao, Shandong 266000, P.R. China

E-mail: nenn808@163.com

*Contributed equally

Key words: gastrointestinal tumors, multidrug resistance 1 gene, P-glycoprotein, expression, ATP-TCA with the occurrence of gastrointestinal tumors, and a negative correlation between the MDRl gene and P-glycoprotein with resistance of chemotherapeutic drugs. Therefore, the MDRI gene and P-glycoprotein can be used as references in the identification and diagnosis of gastrointestinal tumors.

\section{Introduction}

The continuous development of economy and technology have led to improvements in both living standard and quality of life, yet this has been coupled with an increase in several diseases. Fang et al suggested that currently, malignant tumor has become the fourth ranked disease, followed by cardiovascular diseases, hypertension and diabetes (1). Additionally, Ren et al suggested that malignant tumor is a major disease that affects healthy living, and its incidence is $24.6 \%$ of the total incidence in China (2). Wang et al showed that in comparison to tumors on other sites, gastrointestinal tumors (gastric, colon and esophageal cancer) are more accelerated in growth, which leads to difficulty in treating advanced stages, and high recurrence (3). The current treatments of gastrointestinal malignant tumors include surgery, radiation therapy and chemotherapy, the latter of which treatment constitutes the primary treatment.

Oshikata et al identified that different tumor cells have different resistance which influence chemotherapeutic effects to some extent (4). Consequently, it is crucial for studies to be conducted on tumor cell resistance. A study by Correia and Bissell showed that the multidrug resistance (MDR) of tumors causes many different metabolism transduction mechanisms, cytotoxicity (toxic effects of different drugs gather in cells) and other factors, as the resistance of tumor cells is very complex (5). Xuemin and Shusheng demonstrated that as the MDR gene-coded product, $\mathrm{P}$-glycoprotein is mainly located on the surface of the membrane and can participate in intercellular communication and communication among cells as an ATP-dependent transmembrane transporter to some extent (6). Findings have shown that P-glycoprotein can be regarded as cells that indicate a type of channel protein of 
Table I. Experimental design of tumor resistance.

\begin{tabular}{llllll}
\hline Control group & \multicolumn{4}{c}{ Drug groups } \\
\cline { 2 - 6 } & $\begin{array}{c}\text { Concentration 1 } \\
(2 \mathrm{X})\end{array}$ & $\begin{array}{c}\text { Concentration } 2 \\
(1 \mathrm{X})\end{array}$ & $\begin{array}{c}\text { Concentration 3 } \\
(0.5 \mathrm{X})\end{array}$ & $\begin{array}{c}\text { Concentration 4 } \\
(0.25 \mathrm{X})\end{array}$ & $\begin{array}{c}\text { Concentration 5 } \\
(0.125 \mathrm{X})\end{array}$ \\
\hline $\begin{array}{l}\text { Parallel repeat } \\
\text { in three groups }\end{array}$ & $\begin{array}{l}\text { Parallel repeat } \\
\text { in three groups }\end{array}$ & $\begin{array}{l}\text { Parallel repeat } \\
\text { in three groups }\end{array}$ & $\begin{array}{l}\text { Parallel repeat } \\
\text { in three groups }\end{array}$ & $\begin{array}{l}\text { Parallel repeat } \\
\text { in three groups }\end{array}$ & $\begin{array}{l}\text { Parallel repeat } \\
\text { in three groups }\end{array}$ \\
\hline
\end{tabular}

one-way drug output, which can transport intracellular medicine out to decrease intracellular concentrations of relevant drug in the cell $(7,8)$. In this study, according to the expression levels of MDRl gene and P-glycoprotein of gastrointestinal tumors in different tumor environments, we studied the association between MDRl gene, P-glycoprotein and resistance of gastrointestinal tumors in order to provide theoretical and experimental references for reasonable chemotherapeutic drugs in the clinic.

\section{Patients and methods}

General information. In total, 126 cases of patients with gastrointestinal tumors (colon cancer, esophageal cancer and gastric cancer) admitted to the Liaocheng People's Hospital (Shandong, China) from February 2013 to February 2015 were selected for the present study. Prior to the experiment, the subjects did not receive any chemotherapy, radiation therapy or immunotherapy, to treat the gastrointestinal tumors. Following surgery, CT scan and other detection methods, there were 38 samples with colon cancer, 46 samples with esophageal cancer and 42 samples with gastric cancer in 126 tissue samples. The average age of patients was $48.6 \pm 27.3$ years, the disease duration was $4.3 \pm 1.2$ years and there were 87 males and 39 females. There were 47 well-differentiated cases, 38 moderate differentiation cases and 41 poor differentiation cases. This study was approved by the Ethics Committee of Shandong University. Signed written informed consents were obtained from all participants before the study.

\section{Methods}

Clinical specimens. We randomly divided the selected samples into three equal parts and preserved them in liquid nitrogen at $-196^{\circ} \mathrm{C}$. One part was preserved for mRNA extraction, one for detection of the expression of P-glycoprotein and one for ATP-TCA (tumor chemosensitivity assay).

Extraction of RNA in tissue samples and RT-PCR. We extracted RNA from the controls and patients with gastrointestinal tumors in samples (before and after treatment) as described below. Small tissue sample $(0.1 \mathrm{~g})$ was thawed on ice, followed by the addition of $0.45 \mathrm{ml}$ of RNA Plus. The tissue was ground in a pre-cooling mortar in a $1.5-\mathrm{ml}$ tube, followed by the addition of $0.45 \mathrm{ml}$ RNA Plus. The contents were then centrifuged at $1,500 \mathrm{x} g$ for $5 \mathrm{~min}$, followed by the addition of $200 \mu \mathrm{l}$ of chloroform and the tube was agitated for $15 \mathrm{sec}$. The solution was centrifuged again at $10,000 \mathrm{xg}$ for $15 \mathrm{~min}$ at $4^{\circ} \mathrm{C}$. The supernatant was transferred into a new
EP tube containing RNase, equal volumes of isopropanol were added and the samples were placed on the ice for $10 \mathrm{~min}$. The contents were centrifuged again at $10,000 \mathrm{x} \mathrm{g}$ for $10 \mathrm{~min}$ at $4^{\circ} \mathrm{C}$. The supernatant was removed, $750 \mu \mathrm{l}$ of $75 \%$ ethanol was added and gently mixed. The contents were centrifuged again at $10,000 \mathrm{x} \mathrm{g}$ for $10 \mathrm{~min}$ at $4^{\circ} \mathrm{C}$. The supernatant was removed, and residual ethanol was also removed as much as possible. Finally, a moderate volume of water was added to recover the RNA pellet.

Fluorescence quantitative PCR was used to detect the expression of MDRl gene. Oligon 7.0 software was used to design primers (upstream, 5-'CCCATCATTGCAATAGC AGG-3' and downstream, 5'-G3TCAAACTYCTGCTCC TGA-3'). Reaction set up for fluorescence quantitative PCR consisted of $5 \mu \mathrm{l}$ of SYBR-Green and $0.5 \mu \mathrm{l}$ of forward primer, $0.5 \mu \mathrm{l}$ of reverse primer, $1 \mu \mathrm{l}$ of RT product and $3 \mu \mathrm{l}$ of $\mathrm{ddH}_{2} 0$. The reaction was conducted at $95^{\circ} \mathrm{C}$ for $5 \mathrm{~min}$, at $95^{\circ} \mathrm{C}$ for $10 \mathrm{sec}$, at $60^{\circ} \mathrm{C}$ for $30 \mathrm{sec}, 40$ cycles, at $65^{\circ} \mathrm{C}$ for $10 \mathrm{sec}$ and at $95^{\circ} \mathrm{C}$ for $10 \mathrm{sec}$.

P-glycoprotein expression. The expression of P-glycoprotein was measured using enzyme-linked immunosorbent assay (ELISA) (Roche Diagnostics, Basel, Switzerland). Absorbance was measured at $450 \mathrm{~nm}$ after the reaction, and the protein expression was calculated according to the standard protein curve. In addition, we verified the results of ELISA by western blotting, as described elsewhere (9). All kits were purchased from Thermo Fisher Scientific (Waltham, MA, USA). Rabbit monoclonal P-glycoprotein antibody (dilution, 1:500; cat. no. ab170904) and secondary goat anti-rabbit (HRP) IgG antibody (dilution, 1:2,000; cat. no. ab6721) were purchased from Abcam (Cambridge, MA, USA). The procedure was conducted as per instructions of the kit.

Selection of chemotherapeutic drugs. We selected chemotherapeutic drugs with obvious effects on colonic, esophageal and gastric cancer, by including 10 types of drugs, including methotrexate, cisplatin, fluorouracil, adriamycin, paclitaxel, oxaliplatin, calcium folinate, etoposide, xeloda and irinotecan. We used proper concentrations of these chemotherapeutic drugs to conduct related experiments and set proper experimental concentrations. According to pharmacokinetic guidance, we calculated the concentration of plasma value as $(\mu \mathrm{g} / \mathrm{ml})=50 \times$ daily dosage in clinic $(\mathrm{mg} / \mathrm{kg}) 2 \times 10^{3} / 5,000$.

Detection of tumor resistance. We used currently accepted ATP-TCA to perform experiments of chemosensitivity on related tissues. First, we dissected tumor tissues into small 


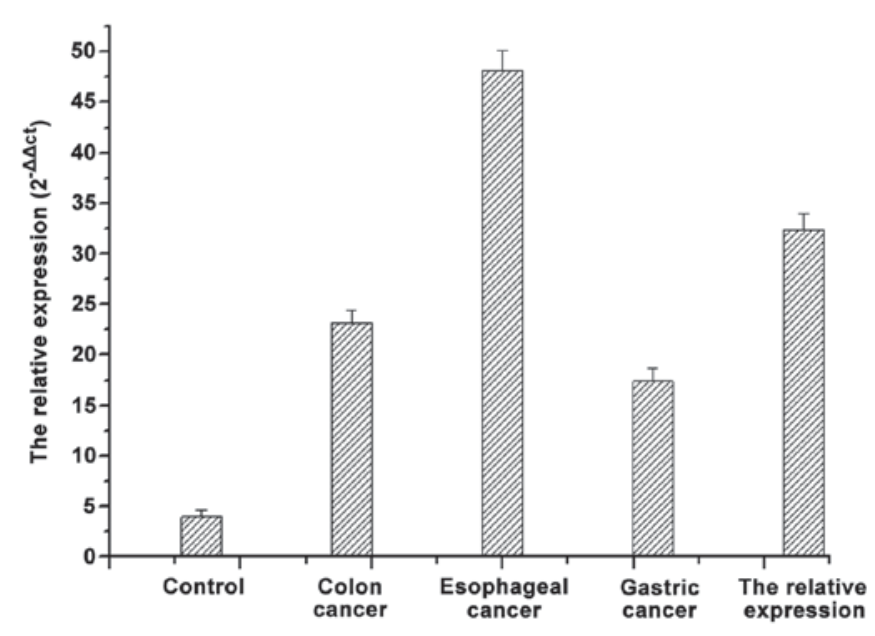

Figure 1. mRNA expression of MDR1 in different gastrointestinal tumors. MDR1, multidrug resistance 1 gene.

Table II. Expression of P-glycoprotein in different gastrointestinal tumors.

\begin{tabular}{|c|c|c|c|c|}
\hline Group & Cases & $\begin{array}{l}\text { Expression of } \\
\text { P-glycoprotein }\end{array}$ & $\chi^{2}$ & P-value \\
\hline Controls & 36 & $4.3-5.2$ & & \\
\hline Esophageal cancer & 46 & $26.4-36.7$ & 98.6 & $<0.05$ \\
\hline Colonic cancer & 38 & $16.4-25.8$ & 95.3 & $<0.05$ \\
\hline Gastric cancer & 42 & $14.3-20.2$ & 94.7 & $<0.05$ \\
\hline
\end{tabular}

sections of $0.5-1 \mathrm{~mm}^{3}$ on ice. Subsequently, pancreatin was used for digestion at $37^{\circ} \mathrm{C}$, with the concentration adjusted to $2 \times 10^{4} / \mathrm{ml}$. Subsequently, single cell suspension was cultivated in a 96-well plate with $2 \times 10^{4}$ cells in each well. The corresponding anticarcinogen was added into each well as described in the experimental design (Table I).

The plates were placed in a 5\% $\mathrm{CO}_{2}$ incubator for 3-4 days at $37^{\circ} \mathrm{C}$, and $0.1 \mathrm{ml}$ of ATP extract of tumor cells was added to the incubator. The plates were placed at room temperature for 20-30 min, and were mixed gently. Mixture $(0.05 \mathrm{ml})$ was taken into the detecting board, and detected after the addition of $0.05 \mathrm{ml}$ of LU-LU. The inhibition ratio was calculated as: $(1$ - (x - Mi)/(Mo - Mi), where x, M0 and Mi were inhibitory rates of fluorescence intensity, and IC50 and IC90 were calculated on the basis of the above data. The effects of different drugs on the inhibitory rates of tumors were evaluated according to the Kurbacher standard.

Statistical analysis. SPSS 20.0 statistical software (Chicago, IL, USA) to analyze obtained data. The data were presented as mean \pm standard deviation to indicate related measurement results, and $\chi^{2}$ was used for the measurement data. $\mathrm{P}<0.05$ was considered statistically significant.

\section{Results}

mRNA expression of MDRI in different gastrointestinal tumors. As shown in Fig. 1, in comparison to the mRNA

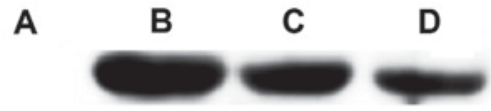

Figure 2. Western blotting for the expression of P-glycoprotein in the controls and patients with different gastrointestinal tumors. (A) Control, and (B) esophageal, (C) colonic and (D) gastric cancers.

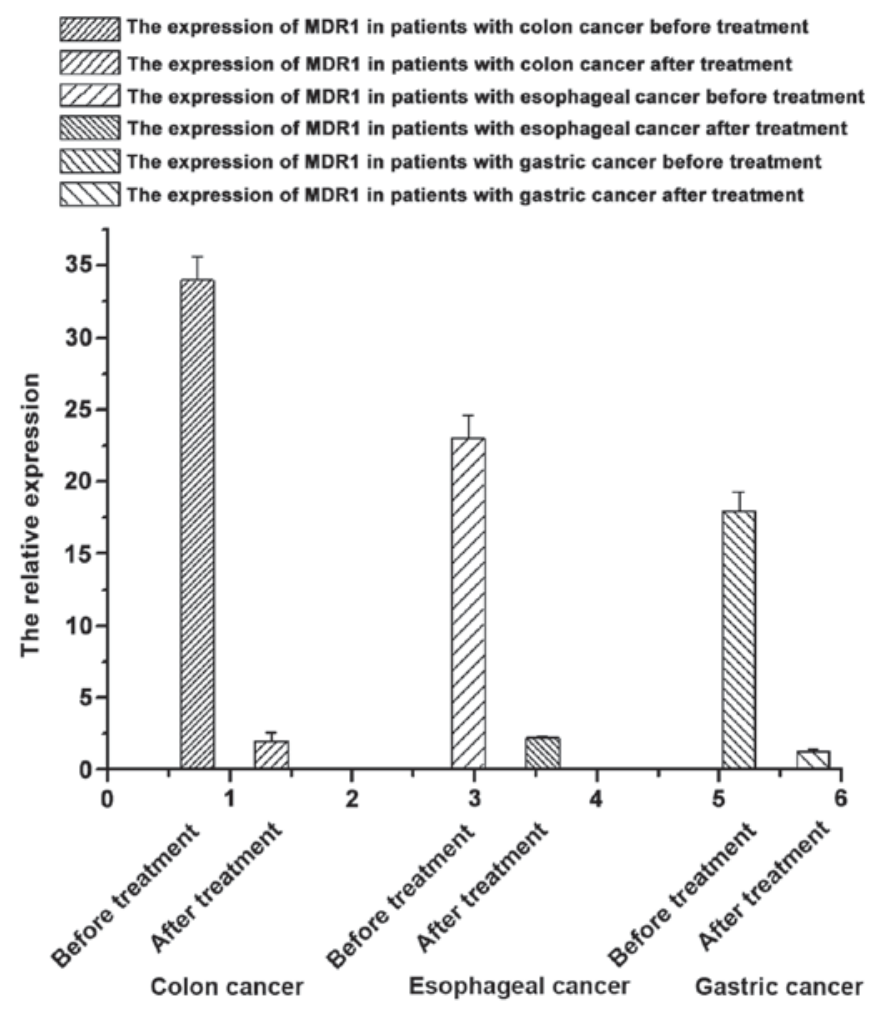

Figure 3. mRNA expression of MDRI in patients with gastrointestinal tumors using the same types of drugs before and after chemotherapy. MDR1, multidrug resistance 1 gene.

expression of MDR1 in tissues of the normal digestive tract, the mRNA expression of MDR1 in samples of patients with gastrointestinal tumor were significantly higher $(\mathrm{p}<0.05)$. The mRNA of MRD1 was differentially expressed in the different gastrointestinal tumors.

Expression of P-glycoprotein in different gastrointestinal tumors. We detected the expression of P-glycoprotein in different gastrointestinal tumors according to ELISA (Table II). In comparison to the control group, the expression of P-glycoprotein in different gastrointestinal tumors was significantly enhanced $(\mathrm{p}<0.05)$ (Table II). We found a similar observation from the western blotting results (Fig. 2). The expression of P-glycoprotein in different gastrointestinal tumors was significantly higher than that in tissues of controls $(p<0.05)$.

Experiments of chemosensitivity by ATP-TCA. We found that different gastrointestinal tumors have different sensitivities to different chemotherapeutic drugs, with gastric cancer having the lowest sensitivity (Table III).

mRNA expression of MDR1 in patients with gastrointestinal tumors using the same type of drugs before and after 
Table III. Detection of sensitivity for different gastrointestinal tumors to different chemotherapeutic drugs.

\begin{tabular}{|c|c|c|c|c|c|}
\hline Items & Cases & $\begin{array}{l}\text { Insensitive to all } \\
\text { chemotherapeutic } \\
\text { drugs }\end{array}$ & $\begin{array}{l}\text { Sensitive to } 1-4 \text { types of } \\
\text { chemotherapeutic drugs }\end{array}$ & $\begin{array}{l}\text { Sensitive to 5-9 types of } \\
\text { chemotherapeutic drugs }\end{array}$ & $\begin{array}{c}\text { Sensitive to all } \\
\text { chemotherapeutic } \\
\text { drugs }\end{array}$ \\
\hline Colonic cancer & 38 & 6 & 11 & 21 & 0 \\
\hline Esophageal cancer & 46 & 0 & 21 & 20 & 5 \\
\hline Gastric cancer & 42 & 16 & 26 & 0 & 0 \\
\hline Total & 126 & 22 & 58 & 41 & 5 \\
\hline
\end{tabular}

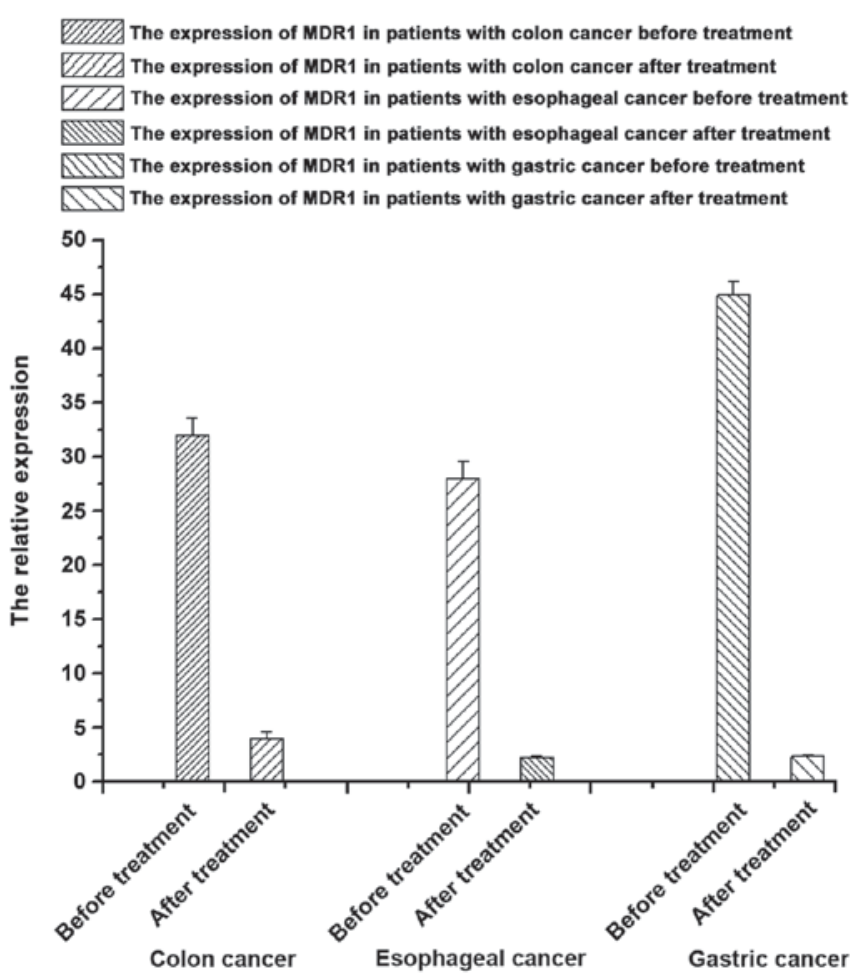

Figure 4. mRNA expression of MDR1 in patients with gastrointestinal tumors using same type of drugs before and after chemotherapy. MDR1, multidrug resistance 1 gene.

chemotherapy. According to the results of the mRNA expression of MDRl in the tissue samples from patients with gastrointestinal tumors before and after chemotherapy (Fig. 3), we found that the mRNA expression of MDRl in samples from patients with gastrointestinal tumors after treatment were significantly lower than that before treatment $(\mathrm{p}<0.05)$, suggesting that chemotherapeutic drugs can decrease the mRNA expression of the MDRl gene.

Expression of $P$-glycoprotein of patients with gastrointestinal tumors using the same type of chemotherapeutic drugs before and after chemotherapy. According to the results of the expression of P-glycoprotein in samples from patients with different gastrointestinal tumors before and after chemotherapy (Table III and Fig. 4), the expression of P-glycoprotein in samples from patients with gastrointestinal tumors after chemotherapy were significantly lower than that before treatment $(p<0.05)$, suggesting that chemotherapeutic drugs can decrease the expression of P-glycoprotein of patients to some extent.

\section{Discussion}

Previous findings suggested that currently, malignant tumors have become a major burden to society $(10,11)$. In recent years, its morbidity in China is on the increase. According to statistical information from the Chinese Health Ministry in 2014, the lethality rate ranks second among urban and rural residents in China, which is almost $25.45 \%$ of the total number of deaths. The current treatments for gastrointestinal tumors are mainly exairesis, radiation therapy and chemotherapy (12-14). Of these treatments, exairesis cannot remove tumors that have formed or transferred (15). Therefore, it is mainly used in the early stage, and it is ineffective in treating malignant tumors, or tumors in the late stages and cancer (16). Compared with exairesis and radiation therapy, chemotherapy has been widely applied in the treatment of malignant tumors, especially gastrointestinal tumors. Statistical information suggests that its total effective rate can reach up to $30 \%$ (17).

During the progress of chemotherapy, the drugs with chemical toxicity enter tumor cells to kill them. Therefore, tumor cell resistance is very important for chemotherapy. Solbach et al suggested that the occurrence of tumor cell resistance to chemotherapeutic drugs can be divided into two categories (18). One is primary drug resistance, meaning it is formed naturally and is not associated with medication in the late stage, and the other is acquired drug resistance, meaning that it is formed by related selectivity of chemotherapy drugs or induction. Previous findings showed that P-glycoprotein containing $M D R 1$ gene encode can be regarded as one-way transport protein in cells $(19,20)$. Additionally, P-glycoprotein can remove chemotherapeutic drugs in tumor cells in order that tumor cells are not killed by chemotherapeutic drugs (21). In this study, we found that the mRNA levels of MDRI in different gastrointestinal tumor cells had substantially increased, and their contents were significantly different from those in controls $(\mathrm{p}<0.05)$. The levels of P-glycoprotein in the controls were also significantly different from those in patients with gastrointestinal tumors $(\mathrm{p}<0.05)$. These results suggest that $M D R 1$ and P-glycoprotein are related to gastrointestinal tumors. According to the analysis of the experimental results of resistance of patients with different gastrointestinal tumors by ATP-TCA, we identified that most gastrointestinal tumors were sensitive to chemotherapeutic drugs, albeit their sensitivity was different. According to detection of the expression of MDR1 and P-glycoprotein in the samples of the same patient before and after chemotherapy, the expression of MDR1 and 
P-glycoprotein after chemotherapy was decreased compared to that before chemotherapy, suggesting chemotherapeutic drugs can influence the expression of MDR1 and P-glycoprotein to some extent to decrease related tumor cell resistance.

\section{References}

1. Fang H, Liang X, Cao Y, Luo H, Si Y, Liu Z and Liu Z: Clinical effects of regional treating chemotherapy on gastrointestinal tumors. Shaanxi Oncol Med 3: 23-32, 2001 (In Chinese).

2. Ren R, Xin XY and Liu SJ: The expressions of PKC- $\alpha$ and P-gp in in Taxol-resistant ovarian cancer cell line A2780/Taxol. J Fourth Military Med Univ 6: 527-529, 2007 (In Chinese).

3. Wang J, Jiang JW, Cai SJ, Peng H, Gao YQ, Cao XD and Wu G: Clinical study on the effect of electroacupuncture on cellular immune function in patients with gastrointestinal tumor. J Acupunct Tuina Sci 6: 67-69, 2011 (In Chinese).

4. Oshikata A, Matsushita T and Ueoka R: Enhancement of drug efflux activity via MDR1 protein by spheroid culture of human hepatic cancer cells. J Biosci Bioeng 111: 590-593, 2011.

5. Correia AL and Bissell MJ: The tumor microenvironment is a dominant force in multidrug resistance. Drug Resist Updat 15: 39-49, 2012.

6. Xuemin L and Shusheng W: The relationship between diversity of MDR1 gene in mammary cancer and its expression and toxicity of hematology caused by chemotherapy. Chin J Gen Surg 11: 78-80, 2012 (In Chinese).

7. Vincent M: Tesmilifene may enhance breast cancer chemotherapy by killing a clone of aggressive, multi-drug resistant cells through its action on the p-glycoprotein pump. Med Hypotheses 66: 715-731, 2006.

8. Rayes N, Seehofer D, Theruvath T, Schiller RA, Langrehr JM, Jonas S, Bengmark S and Neuhaus P: Supply of pre- and probiotics reduces bacterial infection rates after liver transplantation - a randomized, double-blind trial. Am J Transplant 5: 125-130, 2005.

9. Moser JJ, Chan EK and Fritzler MJ: Optimization of immunoprecipitation-western blot analysis in detecting GW182-associated components of GW/P bodies. Nat Protoc 4: 674-685, 2009.

10. Hans N, Maya S, Erich S, Christoph M, Manfred Z, Diethelm W and Tanja F: Predicting resistance to platinum-containing chemotherapy with the ATP tumor chemosensitivity assay in primary ovarian cancer. Anticancer Res 4: 68-72, 2008.
11. Hongzhi J and Suobao L: Progress in progress in the study of human intestinal microecosystem. Nature 26: 88-91, 2003.

12. Ying F: Human-being's knowledge of intestinal microecology steps into a new stage. China Food Daily 1: 32-37, 2010.

13. Loo TW and Clarke DM: Recent progress in understanding the mechanism of P-glycoprotein, mediated drug efflux. J Membr Biol 206: 173-185, 2005.

14. Ambudkar SV, Kim IW and Sauna ZE: The power of the pump: mechanisms of action of P-glycoprotein (ABCB1). Eur J Pharm Sci 27: 392-400, 2006.

15. Shanshan M, Fei J, Hongwen L, Qingjie Z and Jie Z: Effects of P-gp on blood-brain barrier of rat model of chronic Parkinson's disease induced by paraquat and dopaminergic neuron. Apoplexy Neuropsychiatr Illnesses 6: 57-61, 2013.

16. Ma X, Cai Y, He D, Zou C, Zhang P, Lo CY, Xu Z, Chan FL, Yu S, Chen Y, et al: Transient receptor potential channel TRPC5 is essential for P-glycoprotein induction in drug-resistant cancer cells. Proc Natl Acad Sci USA 109: 16282-16287, 2012.

17. Yamada O, Ozaki K, Furukawa T, Machida M, Wang YH, Motoji T, Mitsuishi T, Akiyama M, Yamada H, Kawauchi K, et al: Activation of STAT5 confers imatinib resistance on leukemic cells through the transcription of TERT and MDR1. Cell Signal 23: 1119-1127, 2011.

18. Solbach TF, König J, Fromm MF and Zolk O: ATP-binding cassette transporters in the heart. Trends Cardiovasc Med 16: $7-15,2006$.

19. Binkhathlan Z and Lavasanifar A: P-glycoprotein inhibition as a therapeutic approach for overcoming multidrug resistance in cancer: current status and future perspectives. Curr Cancer Drug Targets 13: 326-346, 2013.

20. Tsang TY, Tang WY, Chan JY, Co NN, Au Yeung CL, Yau PL, Kong SK, Fung KP and Kwok TT: P-glycoprotein enhances radiation-induced apoptotic cell death through the regulation of miR-16 and Bcl-2 expressions in hepatocellular carcinoma cells. Apoptosis 16: 524-535, 2011.

21. Jamroziak K, Młynarski W, Balcerczak E, Mistygacz M, Trelinska J, Mirowski M, Bodalski J and Robak T: Functional C3435T polymorphism of MDR1 gene: an impact on genetic susceptibility and clinical outcome of childhood acute lymphoblastic leukemia. Eur J Haematol 72: 314-321, 2004. 